\title{
Compensation Practice and Job Satisfaction in Selected Consumer Goods in Lagos state Nigeria
}

\author{
Egbuta, Olive U. Ph.D. \\ Department of Business Administration and Marketing \\ Babcock University, Ilisan Nigeria \\ Email: egbutao@babcock.edu.ng
}

Nigeria

Abstract

\begin{abstract}
Job satisfaction in work organization influences the general efficiency and effectiveness of the whole employees. This is usually the results of the compensation practices that predominate in a firm. This paper examined the Compensation practices and how it affects the job satisfaction of employees of selected consumer goods firms in Lagos State, Nigeria. The paper adopted the survey research design through quantitative research approach. Primary data was used through administration of 300 copies of questionnaires to employees in the selected consumer goods firms. Findings reveal that Compensation practice has a positive and significant effect on Job satisfaction $\left(R=0.296\right.$, Adj. $R^{2}=0.071, p<0.05, F$ =11.497). It was found that compensation practice significantly affects job satisfaction of employees of selected consumer goods firms in Nigeria. The paper suggests that managers should always think about what compensation packages really motivate and excite their employees.
\end{abstract}

\section{Keywords: Compensation practice, Job Satisfaction, Consumer goods Firms, Nigeria}

\subsection{Introduction}

Job satisfaction represents one of the most complex and intricate areas facing business owners and managers in business organizations when it comes to managing their employees. Many studies have proven a remarkably huge impact of compensation strategies on the job satisfaction of workers in different industries and work environments. The studies show that the level of compensation has an impact on productivity, and hence also on the performance of business organizations. It is noteworthy that the problems of workers and their work environments cannot be explained entirely by traditional management models and, to appreciate that workers apart from just working to earn a living wage are also looking at the ways to find meaning to life in their jobs. Workers are not just being preoccupied simply with earning a living, they desire more value and benefits in their work. (Armstrong, 2014; Patti, 2000).

The consumer goods industries in Nigeria occupy a very important position and fulfils a very critical economic role for individuals, families and corporate bodies. Employees working in this important economic sector needs to be satisfied with their jobs. The way and manner they are compensated is a very important way to secure the employees' job satisfaction. Phonsanam (2010) holds that owners and companies must understand that there is a direct link between equitable, competitive compensation and increased revenues. Furthermore, when the company irrespective of the industry continue to have the reputation of having high turnover and poor compensation, companies will not be able to attract most industrious and creative workers as their employees. Whenever business owners feel that they cannot have appropriate competitive compensation plans, they should understand the impact of lack of job satisfaction in their employees which includes absenteeism, wilful destruction of equipment, truancy, high labor turnover, low profitability and absence of organizational citizen behavior amongst other deviant behaviors by employees. Consequently, it is more cost-effective to pay a good employee to stay and to be productive, than to incur higher costs arising from employees deviant behavior because of lack of job satisfaction.

Patnaik and Pasha (2012) see compensation as a systematic approach to providing monetary value to employees in exchange for work performed. Compensation may achieve several purposes of assisting in recruitment, job performance, and job satisfaction. In other words, an appropriate compensation management system will help the owners of the business and managers to significantly boost the performance of employees and create a 
more engaged workforce that would be willing to go the extra mile for the achievement of the organization goals and objectives to boost profitability and increase shareholders value.

Compensation comes in different forms to the employees: in form of hourly/weekly wages or annual salary consolidated with other benefits like medical and health insurance, vacation, transportation/travel pass, educational assistance packages, company stock options, and other benefits as may be considered appropriate by the organization and its staff union that can positively affect an employee's work performance. It is a well-structured practice that involves balancing the work employee relation by providing financial and non-financial benefits to employees. Compensation is an integral part of human resource management which helps in motivating the employees and improving organizational effectiveness (Patnaik \& Pasha (2012; Mabaso,2018)

Basic pay which is a component of the compensation package is clearly defined and constitute the major component of the compensation received by employees besides the allowances (Odunlade,2012). Critical and important calculations are predicated on the basic pay which includes hourly and or weekly wage, overtime, and extended hour overtime (include working on public holidays) and other differential calculations while benefits include performance pay like merit increases, incentive pay, bonuses and profit sharing (Bernadin,2007). Odunlade (2012) posited that organizations maintain two pattern of compensation, which includes benefits that are statutorily required to be granted by employers and discretionary benefits as determined by the employer from time to time. Statutory benefits may include life insurance for workers, pension and social security, salary and workmen compensation while discretionary may include performance pay, incentives, medical insurance, annual leave pay, professional membership fee payment, and reimbursement on personal development programs, acting allowances, promotion, among others (Bernadin,2007; Cascio,2003; Odunlade2012, Mabaso,2018). In all, it is to be noted that employees generally respond positively to the payment of incentives (Lazear,2000). Cowgill and Zitzewitz (2015) collaborated from their study that employees respond positively to incentives. Specifically, they found that employees do respond to incentives tied to individual performance, such as those created by the annual promotion cycle. They also found that unvested equity compensation may indirectly affect performance by encouraging retention because employees seem to make retention and performance decisions jointly.

\subsection{Literature Review}

\section{Compensation Practice}

Compensation consists of all forms of financial and non-financial benefits, including tangible and intangible exchanges the employees get for their physical and intellectual abilities engaged by the employer (Bernadin,2007; Bosiri, \& Muya,2019). Compensation consists of direct cash payment made on a regular interval basis, as per the measure of work in scope or quantity or as per the period of engagement for work performed on one part and simultaneously earned benefits while in the employment of the organization (Singh \& Mohanty,2012). The Society for Human Resource Management (SHRM, 2018) defined compensation practice to be a systematic move towards providing a monetary and non-monetary reward to employees in reciprocation of work done. The United States Bureau of Labour Statistics publication defined compensation as various types of non-wage benefits provided to employees, inclusive of normal wages or salaries (USBLS, 2008). Benefits are also referred to as fringe benefits, perquisites or perks enjoyed by employees for holding a post while in the service of an organization. Benefits are good results or advantages gained from something (Webster Dictionary,2018). Mirea, Naftanaila,\& Mirea,.(2012) offered a most comprehensive definition of the employee benefits drawing from the International Accounting Standard IAS 19, perspective defined employee benefits as all forms of consideration given by an entity in exchange for service rendered by employees". This definition further classified these benefits into five groupings namely: short-term employee benefits, (post-employment benefits, other long-term benefits, benefits for the employment termination contract, compensation in the form of the equity participation.

There is a need to clearly define all issues of employees' compensation in the organization, this range from health and medical insurance coverage, pension benefit, monetization, among others (Odunlade, 2012). Klonoski (2016) argued that, even though compensation practice holds very potential for motivation, it does not completely explain why organizations want to offer benefits to their employees. However, governmental regulation of 


\section{(c) Center for Promoting Education and Research}

compensation which makes some benefits statutory thereby creating rights for employees and obligations for employers underscores the importance of compensation (Barry, Minkoff, \& Olsen; 1994; Ford, 1995). Chan, Gee, and Steiner (2000) opined that strategically, managers would want to grant compensation to their employees for the reason of attracting and retaining valuable employees, and of course, the motivating effect on employees' morale. Employer's willingness to discretionarily award benefits is based on inspiring employee loyalty and increasing job satisfaction, as well as organizational commitment (Pandey, \& Khare,, 2012; Weathington \& Tetrick, 2000).

Furthermore, employees are sensitive to and value the criticality of the compensation they get as it determines the kind of lifestyle they can live and the self-esteem that comes with fair and competitive salary (Chan, Gee \& Steiner, 2000). Organizations, in turn, are sensitive to what compensation and pay they give to their employees as it could be a deal-breaker and major determinant of employee decisions concerning accepting to work for an organization, staying on or leaving a job (Cascio, 2003). Researches over decades have consistently established the positive relatedness between compensation and job satisfaction and the relatedness of job satisfaction to employee productivity by way of job performance (Odunlade, 2012), opining that there is direct relatedness of compensation to employee productivity which must be managed for a positive result.

In stressing the vital attention that compensation practice plays in driving employee morale which when positive can boost employee productivity, Gupta and Shaw (2014) posited that compensation is the most critical factor that can influence quality and quantity, as well as efficiency and effectiveness of employee productivity and human resource generally. Gupta, Conroy, and Delery (2012) stated that from a psychological point of view, employee attitude, which has a clear influence on employee performance is greatly affected by compensation adequacy perception. Also, against the assumption that compensation decisions are cost-based, commensurate compensation in terms of output and increased productivity is gained when holistically developed and applied. Additionally, the quality of employees attracted through recruitment, as well as those retained in the corporate talent pool may be profoundly influenced by the quality of the compensation system and administration pattern (Rouen, 2017).

SHRM (2018) noted that since employee benefits make up approximately one-third of total compensation costs, organizations must, therefore, engage in strategic benefits planning to maximize the return on investment. Following a survey which SHRM carried out in February to March 2018 to gather information on the types of benefits, employees offer their employees, and it did confirm that many organizations invest significant resources in designing benefits package and these can be deployed for both new hires in recruitment and for retention of top talents. Therefore, compensation and employee benefits become a very defining practice in the management of Human Resources (Rouen, 2017)

\section{Job Satisfaction}

Fowler, Garety, and Kuipers(2013) referred to job satisfaction as the positive emotions and attitudes employees hold about their job which depends on business-related components, such as the feeling of fulfilment workers get on their day-to-day undertakings and some more. Researchers have identified many other factors that can influence job satisfaction in the workplace; Aziri (2011); Hee, Yan, Rizal, Kowang, and Fei, (2018) have noted that several workforce components can likewise influence job satisfaction. These factors include age, health, and length of job experience, enthusiastic solidness, societal position, family and other social relationships influence their attitudes towards their jobs knowing that they are motivators on how satisfied they are at work ( Lambert, \& Paoline.2008). Hajdukova, Klementova, and Klementova Jnr. (2015); portray job satisfaction as an accurate indicator of good relationships between the employer and the employees because a fulfilled worker, for the most part, should have a decent relationship with the employer. Often lack of job satisfaction reflects the reality of the bad relationship between the employer and the employee.

Job satisfaction from an analytical perspective is being viewed as a behavioral variable. State of mind is characteristic and thoughts which the individual shapes into bearing with his observation about his surrounding (Duvie, 2015). Be that as it may, satisfaction and dissatisfaction are not restricted to the way of the job that one does, additionally relies upon the observation, disposition, and desires towards the job (Ebhote,\& Osemeke, 2015). Also, 


\section{(c) Center for Promoting Education and Research}

WWW.cpernet.org

organizations rely on human capital (employees), and how its employees carry on also relies upon the way the management coordinates the hierarchical undertakings. Job satisfaction is usually linked with motivation, yet the nature of this relationship is not clear because satisfaction is not the same as inspiration. Gantasala, Azzam and Awar (2018) defines Job satisfaction as referring to the level at which employees possess a positive affective orientation towards their employment in an organization...

Fajar (2015), referred job satisfaction to people's feeling about the rewards they have received on the job. Thus satisfaction is related to the consequences of past and present events Aziri (2011), defines job satisfaction as the attitude of workers toward the company, their job, their fellow workers, and other psychological objects in the work environment. Job satisfaction is based on several fundamental factors, among which are the extent that personal job values are compatible with the values and goals of the organization, whether the reward is perceived as a fair compensation for performance, and whether or not rewards are perceived of as being applicable or dependent on performance (Fajar. 2015). The level of job satisfaction explores both the physical and mental well-being of employees and its implication for job-related behaviors such as productivity, absenteeism, and turnover (Ebhote, \& Osemeke,2015). Level of job satisfaction of employees' ranges from extremely satisfied to extremely dissatisfaction level and the satisfaction of employees is not only significant for the employees' comfort but also for the improvement of organizations' performance (Aziri, 2011).

The far-reaching enthusiasm for job satisfaction can be clarified by the way that influences most people because of the generous piece of their lives spent at work. Understanding the components that impact job satisfaction can conceivably prompt to enhancing employee and organizational execution. Kellison, (2009) is of the view that what gives satisfaction varies starting with one employee then unto the next; a few employees may get a high level of utility in their jobs than from the work itself while some may get the best from their jobs, alongside relationship with managers, administrators, and coworkers. Fulfilled employees will probably be focused on their associations and display larger amounts of performance and efficiency. Employee's job satisfaction offers essential clues concerning the wellbeing and execution of an association and gives information on where upgrades can be made to the organization (Ebhote, \& Osemeke, 2015).

\section{Herzberg's Two Factor Theory (The Hygiene Theory of Motivation)}

The two-factor theory (also known as the hygiene theory, dual-factor theory, and Herzberg's motivationhygiene theory) was developed by Herzberg (1968), a clinical psychologist, having investigated and observed 203 accountants and engineers. He postulated that dissatisfaction and satisfaction at work always arose from different factors. The theory posited that certain factors in the workplace cause job satisfaction while a separate set of factors cause dissatisfaction. The theory further stated the independence of satisfiers and dissatisfies. That satisfaction and dissatisfaction are not on a continuum but independent in their effect. The theory suggested that managers must recognize and attend to both sets of job characteristics, which are satisfiers and dissatisfies, to improve job attitude and productivity at work, and not assume that increase in satisfaction leads to decrease in dissatisfaction.

The findings of his investigation were that the job characteristics relating to nature of work performed by a worker can make him happy and satisfied, as well as satisfy needs like recognition, status, personal worth, and selfrealization. However, the absence of such job characteristics may not necessarily lead to unhappiness and dissatisfaction. Dissatisfaction arises from an unfavourable assessment of job-related factors like organizational policies, working conditions, supervision, and job security. Therefore, to increase satisfaction on the job, the management should be focused on the nature of work itself, that is, how employees can gain status, taking responsibility and attaining self-realization. At the same time, to minimize dissatisfaction, managers should focus on job environment factors like policies, working conditions and so on. Nevertheless, management should give concern to both.

The relevance of the theory to the study is established in the sense that it points out the psychological implication of managerial decisions on individual employees, distinguishing what motivates from what does not motivates and what brings about satisfaction from what does not bring about satisfaction. These particularly relate with the varied practices of management in a bid to achieve organizational objectives and requires that conscious 
thinking go into intended and unintended implications, as well as integrating these factors into making informed decisions which have the potentials of affecting productivity in either way.

\subsection{Methodology}

The design adopted for this study is the quantitative research design using the survey design. This design was considered appropriate to investigate the relationships that exist among variables of the research. Data were collected through the primary source by the use of a structured questionnaire. The research instrument was validated and reliability was carried out using the Cronbach Alpha analysis. Three Hundred respondents were surveyed using a structured questionnaire in three consumer goods firms. Data were analysed by inferential statistics using the statistical package for service solutions (SPSS).

Table 1 Research Population

\begin{tabular}{|l|l|c|c|}
\hline S/N & Company & $\begin{array}{l}\text { Population size } \\
\text { per company }\end{array}$ & $\begin{array}{l}\text { Retrieved } \\
\text { questionnaires }\end{array}$ \\
\hline 1 & $\begin{array}{l}\text { Nigeria Breweries Plc. Iganmu } \\
\text { Lagos }\end{array}$ & 100 & 93 \\
\hline 2 & $\begin{array}{l}\text { Guinness Nigeria Plc, Ikeja, } \\
\text { Lagos }\end{array}$ & 100 & 94 \\
\hline 3 & Dangote Plc. Ikeja & 100 & 96 \\
\hline 4 & Total & 300 & $283(94.3 \%)$ \\
\hline
\end{tabular}

\subsection{Data Presentation, Analysis, and Findings}

Three Hundred questionnaires were distributed to employees. Two Hundred and Eighty-Three questionnaires were retrieved indicating a $94.3 \%$ response rate. The study revealed that majority of the respondents are male $(69.2 \%)$, are between the ages of 25-30years (51.6\%), are single (53.0\%), are B.Sc/HND holders $(61.2 \%)$, are middle-level management staffs $(51.8 \%)$ and $48.8 \%$ had 6-10 years length of service.

Restatement of Hypothesis: There is no significant relationship between compensation practice and job satisfaction in selected Consumer goods firms in Lagos State, Nigeria.

\section{Table 2: Model Summary}



a. Predictors: (Constant), COMPENSATION PRACTICE

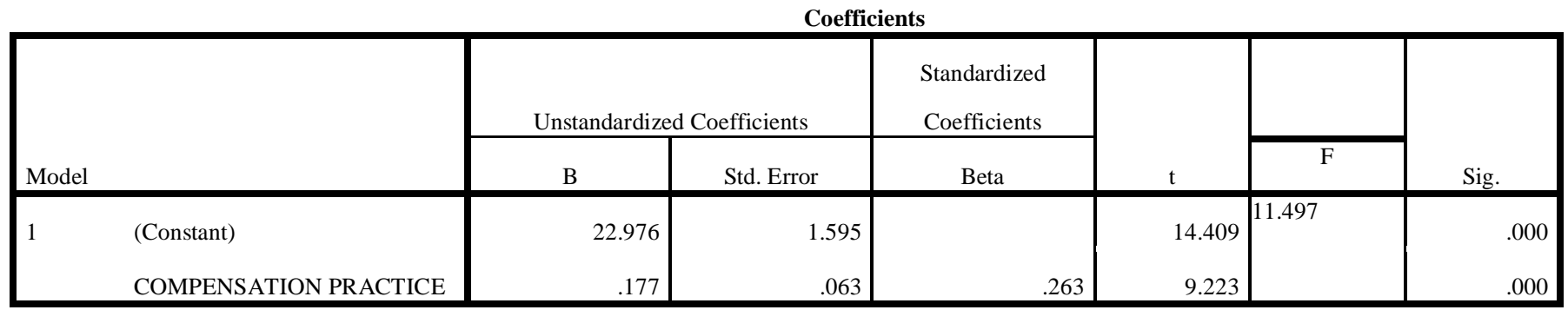

a. Dependent Variable: JOB SATISFACTION

Model for $\left(\mathrm{H}_{01}\right)$ is stated as $\mathrm{y}_{1}=\mathrm{f}\left(\mathrm{x}_{1}\right)$ and $\mathrm{y}_{1}=\alpha_{0}+\beta_{1} \mathrm{x}_{1}+\mu=22.976+0.177 \mathrm{x}_{1}$ 


\section{Interpretation}

Table 1.1 and 1.2 shows that compensation practice has a positive and significant effect on job satisfaction of selected consumer goods firms in Nigeria. Therefore, the null hypothesis which states that there is no significant effect between compensation practice and job satisfaction is rejected $\mathrm{P}<0.05$. The model R2 (coefficient of determination is 0.071 ) which reveals that $7.1 \%$ of variance occurs in compensation practice is explained by job satisfaction while the increasing degree in compensation practice will increase job satisfaction by $(0.177)$.

\section{Discussion}

Qureshi and Sajjid (2015) found out that Job Satisfaction does dovetail and relates positively to other areas of the life of the employees. In another study by Gohari., Ahmadloo, Boroujeni, and Hosseinipour, ( 2013) in which they investigated the relationship between intrinsic and extrinsic compensation on employee performance and which studied tourism companies in Malaysia, using a correlation test analysis, it was found out that both intrinsic and extrinsic compensation have a direct positive relationship with employee performance. Sturman (2006) concluded in his study of the relationship between equitable total compensation and performance that there is a significant relationship between pay and performance with the perception of employees playing important moderation. He concluded that equitable total compensation increases profits because the quality of output is driven by motivated employees. On the other hand, inequitable total compensation as perceived by the employees is likely to lead to employee turnover which may have a negative impact from the perception of the employees and customers, particularly, the quality of output, hence leading to dwindling profitability. This is because costs may be incurred and businesses may be lost.

Sturman (2006) revealed that the bonus system is more influential and effective in driving employee performance. Against the belief of firms that financial incentive is cost induced, calculated and methodical financial incentive often worth giving with proven study outcome of return on investment of more than one thousand percent. He asserted that the increase in wages may give about three hundred and twenty percent return on investment but increase granted inform of wages has the potential of over three thousand percent return on investment. Firms should emphasis and plan more around bonus incentives tied to output and outcomes. In the bonus system, efforts without result go unrewarded whereas reward is earned with results.

Furthermore, Namasivayam, Miao, and Zhao (2006) found that competitive compensation package is positively related to increased and sustained performance of firms. It is given then that proper planning of compensation be done by firms as individual motivating factor differs. Diverse practices with the well thought out plan must be combined to develop an effective compensation system for business success. A single reward element is not likely to be a value driver for performance. Also that the perception of employees about the sufficiency and adequacy of compensation for their efforts used physical and mental strength, will determine the level and quality of output and retainer ship of such employees (Namasivayam et al, 2006, Sturman, 2006)

In the researcher's view compensation, particularly, financial in form of bonus is hyper-performance driving, especially in the mining sector where employees are willing to do more but expect to be adequately compensated for their efforts. The question of adequacy and sufficiency of pay can also be answered through some varying factors, depending on the value and importance placed on the factors by the employer and also the criticality of the personnel and skills possessed in the value chain and value creation. In the compensation system, while efforts are appreciated and compensated with guaranteed minimum pay, the result above minimal expectation is rewarded with the bonus. The guaranteed base pay system ensures everyone gets compensated minimally for efforts engaged but the extra pay is earned through extra performance above the minimum through an outcome measurement system. Firms need to do more as the present-day workforce is more global and competition is tougher than ever before, the emerging labor market is creating competition such that the innovativeness of organizations to attract and retain talents will be a key measurement of their financial performance and survival.

\section{Conclusion and Recommendation}

Compensation practice significantly impacts job satisfaction of selected consumer goods firms in Lagos State, Nigeria. 
The analysis carried out also showed that to a great extent that appropriate and competitive compensation practice is an important requirement to achieve job satisfaction and to embed high organizational performance. The paper recommended that managers should always think about what compensation packages motivate and excite their employees to get optimum performance and high productivity from them.

\section{References}

Armstrong, M. (2014). A Handbook of Human Resources practices. UK: Kogan Publishers P, 985-986.

Aziri, B. (2011). Job satisfaction: a literature review management research and practice. Management Research and Practice, 3(4), 77-86.

Barry, G. Minkoff, H \& Olsen, R. (1994) Employee Compensation: Theory, Practice, and Evidence; Center For Advanced Human Studies (CAHRS) Working Paper $95-04$

Bernadin, M. J. (2007) Human Resources management: An Exponential approach, $4^{\text {th }}$ Ed. New York. McGraw-Hill Irwin pp254-277

Bosiri, R. .K. \& Muya, J. (2019); Non-Monetary Compensation Practices and Employee Output: A Critical Review of Literature. International Journal of Social Sciences and Information Technology ISSN 2412-0294; 5(4), April 2019

Cascio, W.F. (2003). Managing Human Resources: Productivity, Quality of work, life, Profits. 6th ed. New-York: McGraw Hill Higher Education

Chan, K. C., Gee, M. V., \& Steiner, T. L. (2000). Employee Happiness and Corporate Financial Performance. Financial Practice \& Education, 10(2), 47-52.

Cowgill, B \& Zitzewitz, E (2015) Incentive Effects of Equity Compensation: Employee-level Evidence from Google1; www.dartmouth.edu/ ericz/incentives.pdf. Accessed 2nd July 2019

Duvie, A. (2007). The impact of ethnicity and religious affiliation on the alienation of staff from their work environment in Nigerian universities. Journal of Business and Management Sciences 2(1), 1-6.

Ebhote, O \& Osemeke, M. (2015) Conflict Management: Managerial Approach towards Improving Organizational Performance," International Review of Social Sciences and Humanities, 9(1) pp. 51-60

Fajar, S. (2015). Role conflict and stress effect on the performance of employees working in public works department. The International Journal of Engineering and Science (IJES), 4(6), 01-10

Fowler, D., Garety, P \& \& Kuipers, E. (2013) Cognitive Behaviour Therapy for Psychosis: Theory and Practice; Wiley Series in Clinical Psychology. Wiley Inc

Gantasala, S.B., Azzam, A. \& Awar, M. (2015) Determinants and Impact on Job Satisfaction5th Business \& Management Conference, Rome ISBN 978-80-87927-34-2, IISES; DOI: 10.20472/BMC.2017.005.004

Gohari,P., Ahmadloo, A. , Boroujeni, M. B. \& Hosseinipour, S.J.( 2013); The Relationship Between Rewards And Employee Performance; Interdisciplinary Journal Of Contemporary Research In Business. 5(3) ijcrb.webs.com

Gupta, N., Conroy, S., Delery, J., 2012. The many faces of pay variation. Human Resource Management Review 22, $100-115$

Hajdukova, A., Klementova, J.; \& Klementova Jnr., J. (2015); Job Satisfaction as a regulator of the working behaviour; Procedia - Social and Behavioral Sciences 190 (2015) 471-476; Available online at www.sciencedirect.comScienceDirect1877-0428 @ 2015 Published by Elsevier Ltd. 2nd GLOBAL CONFERENCE on PSYCHOLOGY RESEARCHES, 28-29, November 2014

Hee, O. C., Yan, L. H., Rizal, A. M., Kowang, T. O., \& Fei, G. C. (2018). Factors Influencing Employee Job Satisfaction: A Conceptual Analysis. ; International Journal of Academic Research in Business and Social Sciences; $8(6), 331-340$. 
Herzberg, F.(1968). one more time: how do you motivate employees? Harvard Business Review, 46(1) o pp. 5362.

Klonoski, R. (2016) Defining Employee Benefits: A Managerial Perspective; International Journal of Human Resource Studies; ISSN 2162-3058; 6(2) METHROTHINK INSTITUTE.

Lambert, E., \& Paoline. (2008). The Influence of Individual, Job, and Organizational Characteristics on Correctional Staff Job Stress, Job Satisfaction, and Organizational Commitment. Criminal Justice Review; 541-564

Mabaso, C. (2018) Impact of Compensation and Benefits on Job Satisfaction; Journal of Business Management 11(2)

Mirea, V., Naftanaila, C.. \& Mirea, G. (2012) Employee Benefits - Definition, Role, Recognition and Evaluation; International Journal of Academic Research in Economics and Management Sciences September 2012, 1(5) ISSN: $2226-3624$

Namasivayam, K.; Miao, L. \& Zhao, X. R. (2006); an investigation of the relationships between compensation practices and firm performance in the US hotel industry; International Journal of Hospitality Management 26(3):574-587; DOI: 10.1016/j.ijhm

Odunlade, R.O. (2012); Managing Employee Compensation and Benefits for Job Satisfaction in Libraries and Information Centers in Nigeria: Available htt//unlib.unl.edu/LPP/.

Pandey, C \& Khare, R. (2012); Impact of Job Satisfaction and Organizational Commitment on Employee Loyalty; International Journal of Social Science \& Interdisciplinary Research; .1(8);ISSN 22773630. www.indianresearchjournals.com

Patnaik, B.C.M. \& Padhi, P.C. (2012); Compensation Management: A Theoretical Preview; Asian Journal of Marketing \& Management Research; 1(1) ISSN ((1) (PDF) Compensation Management: Available from: online https://www.researchgate.net/publication/259786503_Compensation_Management_A_theoretical_preview[accessed Jul 02 2019]

Phonsanam, S.T. (2010) Total Compensation Practices and Their Relationship to Hospitality Employee Retention.; A professional paper submitted in partial fulfillment of the requirements for the Master of Hospitality Administration ; William F. Harrah College of Hotel Administration; Graduate College University of Nevada, Las Vegas; May 2010

Qureshi, M., Sajja, R (2015). An Empirical Analysis of the Impact of Compensation on Job Performance and WorkFamily Conflict in the Kingdom Of Saudi Arabia-“A Correlation Model; European Scientific Journal 11(4): 170

SHRM (2018); Employee Benefits: The Evolution of Benefits; A Research Report by The Society for Human Resource Management

Singh, R., \& Mohanty, M. (2012). Impact of Training Practices on Employee Productivity: A Comparative Study. Inter science Management Review, 2 (2), 87-92.

Sturman, M.C. (2006). Using your pay system to improve employees' performance: Howyou pay makes a difference. Cornell Hospitality Report, 6(13), 1-16.

Weathington, B \& Tetrick, L. (2000) Compensation or Right: An Analysis of Employee "Fringe" Benefit Perception; Employee Responsibilities and Rights Journal 12(3) · DOI: 10.1023/A: 1011153710102

Webster Dictionary (2018) 